\title{
GFP Transgenic Animals in Biomedical Research: A Review of Potential Disadvantages
}

\author{
N. LIPTÁK ${ }^{1}$, Z. BŐSZE ${ }^{1}$, L. HIRIPI $^{1}$ \\ ${ }^{1}$ NARIC-Agricultural Biotechnology Institute, Animal Biotechnology Department, Gödöllő, \\ Hungary
}

Received June 7, 2018

Accepted July 4, 2018

Epub Ahead of Print July 25, 2019

\begin{abstract}
Summary
Green Fluorescent protein (GFP) transgenic animals are accepted tools for studying various physiological processes, including organ development and cell migration. However, several in vivo studies claimed that GFP may impair transgenic animals' health. Glomerulosclerosis was observed in transgenic mice and rabbits with ubiquitous reporter protein expression. Heart-specific GFP expression evoked dilated cardiomyopathy and altered cardiac function in transgenic mouse and zebrafish lines, respectively. Moreover, growth retardation and increased axon swelling were observed in GFP and yellow fluorescent protein (YFP) transgenic mice, respectively. This review will focus on the potential drawbacks of the applications of GFP transgenic animals in biomedical research.
\end{abstract}

\section{Key words}

GFP • Transgenic animals • Glomerulosclerosis • Dilated cardiomyopathy

\section{Corresponding author}

N. Lipták, NARIC-Agricultural Biotechnology Institute, Animal Biotechnology Department, H-2100 Gödöllő, Szent-Györgyi A st 4, Hungary. E-mail: liptak.nandor@abc.naik.hu

\section{GFP as a fluorescent marker in transgenic animals}

GFP, which was originally discovered in jellyfish Aequorea victoria, absorbs blue light and emits green fluorescence without any exogenous substrates (Shimomura et al. 1962). Several variants of GFP with modified fluorescence spectra were designed in the last two decades, including enhanced GFP (EGFP) (Cormack et al. 1996), YFP (Wachter et al. 1998), Venus (Nagai et al. 2002) etc. EGFP had increased extinction and more efficient folding, whilst Venus showed decreased sensitivity to both acidosis and $\mathrm{Cl}^{-}$compared to wild-type GFP, for more details, see review (Zimmer 2009). The development of the expression vector composed of the chicken $\beta$-actin promoter and cytomegalovirus enhancer (CAGGS), offered a chance for the researchers to create transgenic animals with ubiquitous reporter protein expression (Niwa et al. 1991). After this innovation, GFP or its derivatives were successfully integrated into the genome of laboratory and livestock animals, e.g. mouse (Okabe et al. 1997), pig (Garrels et al. 2011, Park et al. 2001), rabbit (Katter et al. 2013, Takahashi et al. 2007), etc. Recently, EGFP transgenic animals have been used for modelling human diseases (Garcia Diaz et al. 2016, Shetty et al. 2019), tissue engineering (Hirakata et al. 2016) and helped the researchers to reveal the platelet biogenesis in lungs (Lefrancais et al. 2017). Moreover, utilizing of GFP infected chondrocytes was valuable for studying developmental dysplasia and dislocation of the hip in rats (Ning et al. 2019). Initially, most of the studies suggested that GFP is biologically inert. After the creation of GFP transgenic mice, the non-toxic nature of GFP in living cells was questioned by certain researchers (Liu et al. 1999).

\section{Immunogenicity of GFP}

Intravenous administration of wild type pre-leukemia cells cause mortality in Balb/c mice while 
EGFP transformed leukemia cells did not cause systemic leukemia (Stripecke et al. 1999). Further studies indicated that EGFP is highly immunogenic in Balb/c but only moderately immunogenic in other strains like C57BL/6. Not only the strain but also the route of administration of cells influence the level of immune response against EGFP expressing cells (Skelton et al. 2001).

\section{GFP-evoked dilated cardiomyopathy and altered cardiac function}

Dilated cardiomyopathy was detected in transgenic mice with heart-specific GFP overexpression (Huang et al. 2000). In four independent transgenic mouse lines, cardiac-specific GFP expression was driven by the $\alpha$-myosin heavy chain gene ( $\alpha$-MyHC) promoter. Significantly increased heart mass/body mass ratio, fourchamber dilation, relatively thin myocardium was observed in two out of four transgenic FVB/N strains compared to non-transgenic controls. More than half of the 5-weeks old male mice died due to congestive heart failure from one of the two transgenic lines, while mice from the other line developed systolic dysfunction at 4 months of age. The severity of dilated cardiomyopathy positively correlated to the GFP expression level in the heart, suggesting a dose-dependent adverse effect of GFP (Huang et al. 2000). Age-dependent abnormalities in cardiac morphology and function were published using transgenic zebrafish lines with heart-specific GFP expression. Decreased heart rate, stroke volume, and cardiac output (Ho et al. 2007) and altered cardiac function (Avey et al. 2018) were measured in 8-days old and adult myosin light chain 2 gene (cmlc2)-GFP transgenic zebrafishes, respectively, but GFP exerts no detrimental actions on 3-days old zebrafish hearts (Huang et al. 2011). Several attempts were made to discover how GFP overexpression affects cardiac physiology and induces dilated cardiomyopathy. In vitro studies reported that EGFP expression impairs actin-myosin interactions and contractile function of muscle cells (Agbulut et al. 2006, Agbulut et al. 2007), but other research groups did not confirm these findings (Resnicow et al. 2008). In another study, heart-specific co-expression of EGFP and a calmodulin II kinase (CaMKII) inhibitory peptide, autocamtide-3-inhibitor successfully counteracted the EGFPevoked left ventricular dilatation and dysfunction, thus, EGFP may cause increased CaMKII activity in cardiomyocytes which led to dilated cardiomyopathy (Khoo et al. 2008), details are in Table 1. Nevertheless,

Table 1. The collection of the in vivo data of GFP-induced pathology in transgenic animals

\begin{tabular}{|c|c|c|c|}
\hline $\begin{array}{l}\text { Affected } \\
\text { organ systems }\end{array}$ & Transgenic strains & Symptoms & Possible explanations \\
\hline \multirow[t]{2}{*}{$\begin{array}{l}\text { Cardiovascular } \\
\text { system }\end{array}$} & $\begin{array}{l}\alpha \text {-MyHC-EGFP } \\
\text { mice }\end{array}$ & $\begin{array}{l}\text { Dilated cardiomyopathy, } \\
\text { premature death (Huang et al. } \\
\text { 2000). }\end{array}$ & \multirow{2}{*}{$\begin{array}{l}\text { Impaired actin-myosin } \\
\text { interactions (Agbulut et al. } \\
\text { 2006), increased CaMKII } \\
\text { activity (Khoo et al. 2008). }\end{array}$} \\
\hline & $\begin{array}{l}\text { cmlc2-EGFP } \\
\text { zebrafish }\end{array}$ & $\begin{array}{l}\text { Altered cardiac function (Avey } \\
\text { et al. 2018; Ho et al. 2007; } \\
\text { Huang et al. 2011). }\end{array}$ & \\
\hline \multirow[t]{2}{*}{ Urinary tract } & $\begin{array}{l}\text { CAGGS-EGFP } \\
\text { mice }\end{array}$ & $\begin{array}{l}\text { Glomerulosclerosis, proteinuria, } \\
\text { tubulo-interstitial injury (Guo et } \\
\text { al. 2007). }\end{array}$ & \multirow[t]{2}{*}{$\begin{array}{l}\text { Defective polyubiquitination } \\
\text { (Baens et al. 2006), oxidative } \\
\text { stress (Ganini et al. 2017). }\end{array}$} \\
\hline & $\begin{array}{l}\text { GABARAP-EGFP mice } \\
\text { CAGGS-Venus rabbits }\end{array}$ & $\begin{array}{l}\text { Glomerulosclerosis, proteinuria } \\
\text { (Takagi-Akiba et al. 2012), } \\
\text { (Liptak et al. 2018). }\end{array}$ & \\
\hline \multirow[t]{2}{*}{$\begin{array}{l}\text { Central nervous } \\
\text { system }\end{array}$} & lacZ-GFP mice & $\begin{array}{l}\text { Growth retardation, premature } \\
\text { death (Krestel et al. 2004). }\end{array}$ & \multirow[t]{2}{*}{$\begin{array}{l}\text { GFP/YFP excessive } \\
\text { aggregation/accumulation. }\end{array}$} \\
\hline & Thy-1 YFP mice & $\begin{array}{l}\text { Increased axon swelling (Bridge } \\
\text { et al. 2009). }\end{array}$ & \\
\hline
\end{tabular}

Abbreviations: a-MyHC: a-myosin heavy chain gene, cmcl2: myosin light chain 2 gene, CamKII: calmodulin II kinase, GABARAP: $y$ Aminobutyric acid $A$ receptor-associated protein. 
mild hypertrophy and cardiomyopathy was observed in $\alpha$-MyHC tetracycline transactivator transgenic mice (McCloskey et al. 2005), indicating that overexpression of any protein in the heart under the control of $\alpha-\mathrm{MyHC}$ promoter may cause cardiomyopathy.

\section{GFP-evoked glomerulosclerosis}

In most cases, ubiquitous expression EGFP or its variants under the control of the CAGGS promoter did not affect fecundity (Garrels et al. 2012, Hoffmann et al. 2016), life span and had no measurable detrimental effect (Chou et al. 2014, Garrels et al. 2011, Yum et al. 2018).

Nowadays, CAGGS-EGFP transgenic mice (C57BL/6-Tg(CAG-EGFP)1Osb/J, Jackson Laboratories) with ubiquitous reporter protein expression (Okabe et al. 1997) are one of the most popular transgenic animals in biomedical research. However, 5-weeks old CAGGS-EGFP transgenic mice developed mild glomerulosclerosis and proteinuria (Guo et al. 2007). The pathological progression was slow, age-dependent and did not affect the life-span of the mice. Only CAGGSEGFP transgenic mice with the highest EGFP expression in their glomeruli developed glomerulosclerosis. Three other transgenic strains with lower glomerular GFP expression showed normal renal histology, suggesting that high EGFP levels may have harmful effects on the glomeruli (Guo et al. 2007). Supporting these findings, more severe proteinuria and glomerulosclerosis were observed in an EGFP- $\gamma$-Aminobutyric acid A receptorassociated protein (GABARAP) transgenic mouse strain after a single doxorubicin injection compared with non-transgenic mice (Takagi-Akiba et al. 2012). Mild proteinuria, focal segmental glomerulosclerosis (FSGS) and glomerulomegaly were also detected in heterozygote CAGGS-Venus transgenic rabbits, while homozygote Venus transgenic rabbits developed FSGS, glomerulomegaly and microscopic hematuria, but not proteinuria (Liptak et al. 2018). Similarly to CAGGSEGFP transgenic mice, the mild glomerulosclerosis did not affect the life span. The Venus transgene was integrated at chromosome 8, at 61471914 bp (Katter et al. 2013) in the intron 12-13 of the diaphanous related formin 3 gene (DIAPH3, Ensembl gene ID: ENSOCUG00000001719), thus, it is unlikely that the integration site of the transgene caused the FSGS. These data suggested that glomerulosclerosis in transgenic animals overexpressing the reporter GFP or its variants (EGFP, Venus) is not limited to mice. The underlying mechanisms of GFP-associated glomerulosclerosis are not clear, however, defective polyubiquitination (Baens et al. 2006) and oxidative stress (Ganini et al. 2017, Goto et al. 2003) may have a role in the development of glomerular lesions. EGFP produces $\mathrm{H}_{2} \mathrm{O}_{2}$ and superoxide anion during its maturation in the presence of $\mathrm{NADH}$, but these findings were restricted to E. coli and HeLA cell lines to date (Ganini et al. 2017) (Table 1).

\section{GFP-induced neuropathology}

EGFP and $\beta$-galactosidase co-expression in the forebrain caused growth retardation, weakness and premature death in 25-30 days old transgenic mice from two independent lines (Krestel et al. 2004). GFP alone did not have any of the abovementioned neuropathological effects in a third transgenic mouse line. The cytoplasmic aggregation of EGFP and $\beta$-galactosidase could be responsible for the premature death in the two transgenic lines. Doxycycline and granulocyte colony-stimulating factor (GCSF) treatment were effective in the prevention of early death of transgenic mice co-expressing EGFP and $\beta$-galactosidase, but did not prevent them from growth retardation (Krestel et al. 2004). Doxycycline exerted its effect via downregulation of the EGFP expression, while GCSF had neuroprotective effect which was published earlier (Schabitz et al. 2003).

In YFP transgenic mice, more severe axon swelling was observed in gracile tract, gracile nucleus and dorsal roots compared to non-transgenic mice at 8 and 12 months of age (Bridge et al. 2009). YFP expression was driven by the neuron-specific Thy-1 promoter in the transgenic mice. Unfortunately, the exact genomic position of the YFP coding transgene is not available. Increased axon swelling was attributed by the excessive accumulation of the YFP in the central nervous system and not the position effect of the transgene (Bridge et al. 2009). These observations were underlined by an independent research group later (Gatto et al. 2015) (Table 1).

\section{Conclusions}

In the majority of GFP transgenic animal lines, GFP did not have any detectable harmful effect on animals' health, but there were a few exceptions. Heartspecific GFP overexpression caused dilated cardiomyopathy in mice and altered cardiac function in 
zebrafish. Transgenic mouse and rabbit strains with CAGGS promoter-driven ubiquitous EGFP or Venus expression developed mild glomerulosclerosis and proteinuria. Neuron-specific expression of YFP and co-expression of EGFP and $\beta$-galactosidase caused pathologic symptoms in mouse strains created by different research groups. These findings should be considered when in vivo studies using GFP transgenic animals are designed.

\section{Conflict of Interest}

There is no conflict of interest.

\section{Acknowledgements}

This work was supported by the National Research, Development and Innovation Office (NKFIH) grant no. 108921, NVKP_16-1-2016-0039 to Z. B. and 120870 to N. L.

\section{References}

AGBulut O, COIRAUlT C, NIEDERLANDER N, HUET A, VICART P, HAGEGE A, PUCEAT M, MENASCHE P: GFP expression in muscle cells impairs actin-myosin interactions: implications for cell therapy. Nat Methods 3: 331, 2006.

AGBUlut O, HUET A, NIEDERLANDER N, PUCEAT M, MENASCHE P, COIRAULT C: Green fluorescent protein impairs actin-myosin interactions by binding to the actin-binding site of myosin. $J$ Biol Chem 282: 10465-10471, 2007.

AVEY SR, OJEHOMON M, DAWSON JF, GILLIS TE: How the expression of green fluorescent protein and human cardiac actin in the heart influences cardiac function and aerobic performance in zebrafish Danio rerio. $J$ Fish Biol 92: 177-189, 2018.

BAENS M, NOELS H, BROECKX V, HAGENS S, FEVERY S, BILLIAU AD, VANKELECOM H, MARYNEN P: The dark side of EGFP: defective polyubiquitination. PLoS One 1: e54, 2006.

BRIDGE KE, BERG N, ADALBERT R, BABETTO E, DIAS T, SPILLANTINI MG, RIBCHESTER RR, COLEMAN MP: Late onset distal axonal swelling in YFP-H transgenic mice. Neurobiol Aging 30: 309-321, 2009.

CHOU CJ, PENG SY, WU MH, YANG CC, LIN YS, CHENG WT, WU SC, LIN, YP: Generation and characterization of a transgenic pig carrying a DsRed-monomer reporter gene. PLoS One 9: e106864, 2014.

CORMACK BP, VALDIVIA RH, FALKOW S: FACS-optimized mutants of the green fluorescent protein (GFP). Gene 173: 33-38, 1996.

GANINI D, LEINISCH F, KUMAR A, JIANG JJ, TOKAR EJ, MALONE CC, PETROVICH RM, MASON RP: Fluorescent proteins such as eGFP lead to catalytic oxidative stress in cells. Redox Biol 12: 462-468, 2017.

GARCIA DIAZ AI, MOYON B, COAN PM, ALFAZEMA N, VENDA L, WOOLLARD K, AITMAN T: New Wistar Kyoto and spontaneously hypertensive rat transgenic models with ubiquitous expression of green fluorescent protein. Dis Model Mech 9: 463-471, 2016.

GARRELS W, HOLLER S, CLEVE N, NIEMANN H, IVICS Z, KUES WA: Assessment of fecundity and germ line transmission in two transgenic pig lines produced by sleeping beauty transposition. Genes (Basel) 3: 615-633, 2012.

GARRELS W, MATES L, HOLLER S, DALDA A, TAYLOR U, PETERSEN B, NIEMANN H, IZSVAK Z, IVICS Z, KUES WA: Germline transgenic pigs by sleeping beauty transposition in porcine zygotes and targeted integration in the pig genome. PLoS One 6: e23573, 2011.

GATTO RG, CHU Y, YE AQ, PRICE SD, TAVASSOLI E, BUENAVENTURA A, BRADY ST, MAGIN RL, KORDOWER JH, MORFINI GA: Analysis of YFP(J16)-R6/2 reporter mice and postmortem brains reveals early pathology and increased vulnerability of callosal axons in Huntington's disease. Hum Mol Genet 24: 5285-5298, 2015.

GOTO H, YANG B, PETERSEN D, PEPPER KA, ALFARO PA, KOHN DB, REYNOLDS CP: Transduction of green fluorescent protein increased oxidative stress and enhanced sensitivity to cytotoxic drugs in neuroblastoma cell lines. Mol Cancer Ther 2: 911-917, 2003. 
GUO JK, CHENG EC, WANG L, SWENSON ES, ARDITO TA, KASHGARIAN M, CANTLEY LG, KRAUSE DS: The commonly used beta-actin-GFP transgenic mouse strain develops a distinct type of glomerulosclerosis. Transgenic Res 16: 829-834, 2007.

HIRAKATA E, TOMITA N, TAMADA Y, SUGURO T, NAKAJIMA M, KAMBE Y, YAMADA K, YAMAMOTO K, KAWAKAMI M, OTAKA A, OKUMURA H, SUZUKI S: Early tissue formation on whole-area osteochondral defect of rabbit patella by covering with fibroin sponge. J Biomed Mater Res B Appl Biomater 104: 1474-1482, 2016.

HO YL, LIN YH, TSAI IJ, HSIEH FJ, TSAI HJ: In vivo assessment of cardiac morphology and function in heartspecific green fluorescent zebrafish. J Formos Med Assoc 106: 181-186, 2007.

HOFFMANN OI, KEREKES A, LIPTAK N, HIRIPI L, BODO S, SZALOKI G, KLEIN S, IVICS Z, KUES WA, BOSZE Z: Transposon-based reporter marking provides functional evidence for intercellular bridges in the male germline of rabbits. PLoS One 11: e0154489, 2016.

HUANG W, DENG Y, DONG W, YUAN W, WAN Y, MO X, LI Y, WANG Z, WANG Y, OCORR K, ZHANG B, LIN S, WU X: The effect of excess expression of GFP in a novel heart-specific green fluorescence zebrafish regulated by nppa enhancer at early embryonic development. Mol Biol Rep 38: 793-799, 2011.

HUANG WY, ARAMBURU J, DOUGLAS PS, IZUMO S: Transgenic expression of green fluorescence protein can cause dilated cardiomyopathy. Nature Med 6: 482-483, 2000.

KATTER K, GEURTS AM, HOFFMANN O, MATES L, LANDA V, HIRIPI L, MORENO C, LAZAR J, BASHIR S, ZIDEK V, POPOVA E, JERCHOW B, BECKER K, DEVARAJ A, WALTER I, GRZYBOWSKI M, CORBETT M, RANGEL A, HODGES MR, BADER M, IVICS Z, JACOB HJ, PRAVENEC M, BOSZE Z, RULICKE T, IZSVAK Z: Transposon-mediated transgenesis, transgenic rescue, and tissue-specific gene expression in rodents and rabbits. Faseb Journal 27: 930-941, 2013.

KHOO MS, GRUETER CE, EREN M, YANG J, ZHANG R, BASS MA, LWIN ST, MENDES LA, VAUGHAN DE, COLBRAN RJ, ANDERSON ME: Calmodulin kinase II inhibition disrupts cardiomyopathic effects of enhanced green fluorescent protein. J Mol Cell Cardiol 44: 405-410, 2008.

KRESTEL HE, MIHALJEVIC AL, HOFFMAN DA, SCHNEIDER A: Neuronal co-expression of EGFP and beta-galactosidase in mice causes neuropathology and premature death. Neurobiol Dis 17: 310-318, 2004.

LEFRANCAIS E, ORTIZ-MUNOZ G, CAUDRILLIER A, MALLAVIA B, LIU FC, SAYAH DM, THORNTON EE, HEADLEY MB, DAVID T, COUGHLIN SR, KRUMMEL MF, LEAVITT AD, PASSEGUE E, LOONEY MR: The lung is a site of platelet biogenesis and a reservoir for haematopoietic progenitors. Nature 544: 105-109, 2017.

LIPTAK N, HOFFMANN OI, SKODA G, GOCZA E, KEREKES A, BOSZE Z, HIRIPI L: Glomerulosclerosis in transgenic rabbits with ubiquitous venus protein expression. Acta Veterinaria Hungarica 66: 281-293, 2018.

LIU HS, JAN MS, CHOU CK, CHEN PH, KE NJ: Is green fluorescent protein toxic to the living cells? Biochem Biophys Res Commun 260: 712-717, 1999.

MCCLOSKEY DT, TURNBULL L, SWIGART PM, ZAMBON AC, TURCATO S, JOHO S, GROSSMAN W, CONKLIN BR, SIMPSON PC, BAKER AJ: Cardiac transgenesis with the tetracycline transactivator changes myocardial function and gene expression. Physiol Genomics 22: 118-126, 2005.

NAGAI T, IBATA K, PARK ES, KUBOTA M, MIKOSHIBA K, MIYAWAKI A: A variant of yellow fluorescent protein with fast and efficient maturation for cell-biological applications. Nat Biotechnol 20: 87-90, 2002.

NING B, JIN R, WANG D, SUN J: The H19/let-7 feedback loop contributes to developmental dysplasia and dislocation of the hip. Physiol Res 68: 275-284, 2019.

NIWA H, YAMAMURA K, MIYAZAKI J: Efficient selection for high-expression transfectants with a novel eukaryotic vector. Gene 108: 193-199, 1991.

OKABE M, IKAWA M, KOMINAMI K, NAKANISHI T, NISHIMUNE Y: 'Green mice' as a source of ubiquitous green cells. FEBS Lett 407: 313-319, 1997.

PARK KW, CHEONG HT, LAI LX, IM GS, KUHHOLZER B, BONK A, SAMUEL M, RIEKE A, DAY BN, MURPHY CN, CARTER DB, PRATHER RS: Production of nuclear transfer-derived swine that express the enhanced green fluorescent protein. Anim Biotechnol 12: 173-181, 2001. 
RESNICOW DI, HOOFT AM, HARRISON BC, BAKER JE, LEINWAND LA: GFP fails to inhibit actin-myosin interactions in vitro. Nature Methods 5: 212-213, 2008.

SCHABITZ WR, KOLLMAR R, SCHWANINGER M, JUETTLER E, BARDUTZKY J, SCHOLZKE MN, SOMMER C, SCHWAB S: Neuroprotective effect of granulocyte colony-stimulating factor after focal cerebral ischemia. Stroke 34: 745-751, 2003.

SHETTY G, WU Z, LAM TNA, PHAN TT, ORWIG KE, MEISTRICH ML: Effect of hormone modulations on donorderived spermatogenesis or colonization after syngeneic and xenotransplantation in mice. Andrology 7: 257-265, 2019.

SHIMOMURA O, JOHNSON FH, SAIGA Y: Extraction, purification and properties of aequorin, a bioluminescent protein from the luminous hydromedusan, Aequorea. J Cell Comp Physiol 59: 223-239, 1962.

SKELTON D, SATAKE N, KOHN DB: The enhanced green fluorescent protein (eGFP) is minimally immunogenic in C57BL/6 mice. Gene Therapy 8: 1813-1814, 2001.

STRIPECKE R, VILLACRES MD, SKELTON DC, SATAKE N, HALENE S, KOHN DB: Immune response to green fluorescent protein: implications for gene therapy. Gene Therapy 6: 1305-1312, 1999.

TAKAGI-AKIBA M, ASANUMA K, TANIDA I, TADA N, OLIVA TREJO JA, NONAKA K, ASANUMA E, KOMINAMI E, UENO T, TOMINO Y: Doxorubicin-induced glomerulosclerosis with proteinuria in GFP-GABARAP transgenic mice. Am J Physiol Renal Physiol 302: F380-F389, 2012.

TAKAHASHI R, KURAMOCHI T, AOYAGI K, HASHIMOTO S, MIYOSHI I, KASAI N, HAKAMATA Y, KOBAYASHI E, UEDA M: Establishment and characterization of CAG/EGFP transgenic rabbit line. Transgenic Res 16: 115-120, 2007.

WACHTER RM, ELSLIGER MA, KALLIO K, HANSON GT, REMINGTON SJ: Structural basis of spectral shifts in the yellow-emission variants of green fluorescent protein. Structure 6: 1267-1277, 1998.

YUM SY, LEE SJ, PARK SG, SHIN IG, HAHN SE, CHOI WJ, KIM HS, KIM HJ, BAE SH, LEE JH, MOON JY, LEE WS, LEE JH, LEE CI, KIM SJ, JANG G: Long-term health and germline transmission in transgenic cattle following transposon-mediated gene transfer. BMC Genomics 19: 387, 2018.

ZIMMER M: GFP: from jellyfish to the Nobel prize and beyond. Chem Soc Rev 38: 2823-2832, 2009. 